\title{
THE SOCIAL AND CULTURAL DiMENSIONS OF THE ROLE OF ETHNIC CHINESE IN INDONESIAN SOCIETY
}

\author{
Mély G. Tan
}

Interest in the ethnic Chinese in Indonesia and in other Southeast Asian countries has continued unabated largely because of the important role they continue to play in the economy, and in at least one country, in the polity. Not surprisingly, most studies of the ethnic Chinese have concentrated on these two areas.

However, the social and cultural dimensions of their role have not been entirely neglected. ${ }^{1}$ In Indonesia, the interest in these dimensions is, perhaps, also generated by the

This is a revised and updated version of a paper presented at the Symposium on the Role of Indonesian Chinese in Indonesian Life, Cornell University, July 13-15, 1990. This paper with the same title, was originally presented at the joint CCSEAS/NWRSEA Conference at the Asian Centre of the University of British Columbia, Vancouver, B.C., Canada, November 3-5, 1989.

${ }^{1}$ See an early sociological study by Ong Eng Die, De Chineezen in Nederlandsch Indië: Sociografie van een Indonesische bevolkingsgroep (The Chinese in the Dutch East Indies) (Assen: Van Gorcum, 1943), his doctoral dissertation, written from secondary sources while he was in the Netherlands during World War II; Edward J. Ryan, "The Value System of a Chinese Community in Java" (Ph.D. diss., Harvard University, 1961). See more recent studies on the role of ethnic Chinese in the development of the press in Indonesia, on education, and on religion in Leo Suryadinata, The Pre-World War II Peranakan Chinese Press of Java: A Preliminary Survey (Athens: Ohio University Center for International Studies, Southeast Asia Paper No. 18, 1971); idem, The Chinese Minority in Indonesia, 7 papers. (Singapore: Chopmen Enterprises, 1978); idem, Kebudayaan Minoritas Tionghoa di Indonesia, (The culture of the Chinese minority in Indonesia), trans. Dédé Oetomo (Jakarta: Gramedia, 1988). Jennifer W. Cushman and Wang Gungwu, eds., Changing Identities of Southeast Asian Chinese Since World War II, (Hong Kong: Hong Kong University Press, 1988); L. A. Peter Gosling and Linda Y. C. Lim, The Chinese in Southeast Asia, vol. 2, Identity, Culture and Politics (Singapore: Maruzen, 1983); the monumental work on what has been referred to as "ChineseMalay," "Sino-Malay," or "Melayu-Tionghoa" literature, in Claudine Salmon, Literature in Malay by the Chinese of Indonesia: A Provisional Annotated Bibliography (Paris: de la Maison des Sciences de l'Homme, 1981). See also Myra Sidharta, ed., 100 Tahun Kwee Tek Hoay, Dari Penjaja Tekstil Sampai ke Pendekar Pena (100th anniversary of Kwee Tek Hoay, from textile peddler to fighter with the pen) (Jakarta: Pustaka Sinar Harapan, 1989). Since the 1980s, a number of theses and dissertations have been written by Indonesian students at universities in Indonesia or abroad focusing on the social and cultural lives of the ethnic Chinese and their relations with the majority population. These include: Danny Indrakusuma, "Posisi berbeda agama dalam hubungan Cina-Pribumi: Suatu studi tentang persepsi masyarakat Cina di Kota Solo" (Skripsi Sarjana Sosiologi, Fisipol, Universitas Airlangga, Surabaya, 1987); A. H. Kurniawan, "Identifikasi Pelajar SMA Keturunan Tionghoa di Jakarta" (Skripsi Sarjana 
realization that twenty-three years have passed since the New Order government implemented a series of regulations with the expressed intent of accelerating the process of pembauran, or assimilation. ${ }^{2}$ These regulations were announced in the form of instructions or decisions on the presidential and ministerial level. The first, on "The Basic Policy for the Solution of the Chinese Problem" was promulgated in June 1967 and was followed in December of the same year by another on religion, beliefs, and Chinese customs. ${ }^{3}$ In addition, a number of specific regulations pertained to the education of ethnic Chinese children whose parents were Indonesian citizens as well as those whose parents were aliens.

From these regulations it is clear that for the government, assimilation, defined as the eventual disappearance of a group as a sociocultural entity, is the best way to resolve what is usually referred to as the "Chinese problem" (masalah Cina). This legacy of the colonial past has persisted and in some ways has been aggravated since independence. The problem is the existence in society of a relatively small (estimated at around 3 percent) but highly significant group, which the ethnic Indonesian majority perceive as alien in appearance and culture. In their view, the group's grip on the economy is disproportionate to its numbers, and it tends to segregate itself socially and residentially, a behavior they see as an arrogant expression of feelings of superiority. These perceived characteristics have generated resentment towards the group, which at times has exploded into actions of violence against them.

One should be aware that this policy is not a product of the New Order government alone. President Sukarno also espoused the idea of assimilation, although he was not as insistent about it as the present government. At the time, he also allowed an opposing view to flourish, no doubt to balance the assimilationist view. This opposite view, propounded by the ethnic Chinese mass organization Baperki, supported integration rather than assimilation. ${ }^{4}$ Baperki defined integration to mean the acceptance of the ethnic Chinese as an integral part of Indonesian society by recognizing the validity of their existence as a social entity similar to indigenous ethnic groups. In the aftermath of the 1965 abortive coup, this organization was banned because of its close relations with the Indonesian Communist party.

Since 1965, assimilationist perspective has prevailed, and the present government seems determined to accelerate the process through regulation. It is evident that the cultural factor

Sosiologi, Fisip-UI, 1984); Dédé Oetomo, "The Chinese of Pasuruan: A Study of Language and Identity in a Minority Community in Transition" (Ph.D. diss., Cornell University, 1984); Stephen Suleeman, "Persepsi golongan keturunan Tionghoa Indonesia terhadap golongan bumi putera" (Skripsi Sarjana Ilmu Komunikasi, 1986); and Hendra Sutedjo, "Komunikasi dan tingkat suami-istri perkawinan campuran" (Skripsi Sarjana Ilmu Komunikasi, Fisip-UI, 1984).

${ }^{2}$ The root of this word is baur, meaning to mix. In the context of intergroup relations in Indonesia, it means "to assimilate."

${ }^{3}$ Instruction of the Cabinet Presidium no. 37/U/IN/6/1967, "The Basic Policy for the Solution of the Chinese Problem," sanctioned in Jakarta on June 7, 1967, and signed by Suharto as chairman of the Ampera Cabinet Presidium; Instruction of the president of the Republic of Indonesia no. 14, 1967, on religion, beliefs, and Chinese customs sanctioned in Jakarta on December 6, 1967, and signed by Suharto as acting president of the Republic of Indonesia; Coordinating Body for the Chinese Problem-Coordinating Body for National Intelligence, comp., Pedoman penyelesaian masalah Cina di Indonesia (Handbook for the resolution of the Chinese problem in Indonesia), vol. 1 (Bakin: Jakarta, 1979). Volume 1 comprises the policies for the resolution of the Chinese problem, the technical instructions, and a compilation of the laws for the basic policies. Volume 2 is a compilation of the laws concerning the general handbook (pedoman umum), and volume 3 is a compilation of the laws concerning policy implementation and implementation organization.

${ }^{4}$ The Badan Permusjawaratan Kewarganegaraan Indonesia (Consultative Body for Indonesian Citizenship) was established in March 1954. It participated in the national elections of 1955 and received wide support in the ethnic Chinese community. 
is considered the main obstacle to this process. Hence as stated in the regulations, "Guidance in assimilation in the framework of the realization of unity of the nation should be geared towards the establishment of unity in the value system." To this end, "All forms of cultural affinity based on the country of origin should be removed, in order to give all elements of culture in Indonesia the opportunity to develop according to the Pancasila." 5

In view of the importance given to the cultural factor it seems appropriate to assess how these regulations have been implemented and how the ethnic Chinese have responded to them. No doubt these responses have varied in time and place by age and cultural orientation. Nonetheless, indications are that the general response has been compliance, albeit sometimes mixed with covert reluctance. Whenever possible, however, people also attempt to ignore or get around the regulations.

This attitude of compliance can be seen as a manifestation of the powerlessness of the ethnic Chinese and their total lack of bargaining power. Although they are perceived by the ethnic Indonesian majority to dominate the economy, a recent event vividly illustrates their weak position-the response of ethnic Chinese big businessmen to the appeal of President Suharto on March 4, 1990, to sell up to 25 percent of the shares of their companies to cooperatives. Although their immediate response was positive, recognizing the validity of Suharto's expressed motivation-the concern for the effects of social inequity-they later noted privately as well as publicly the grave uncertainties in the implementation of the idea. Still, their overall response again was compliance. ${ }^{6}$

An assessment of the persistent Chinese problem is pertinent now that the Indonesian government has finally resumed diplomatic relations with the People's Republic of China after freezing relations for twenty-three years. This prolonged freeze is alleged to be owing to the view, espoused especially among the military, that normalization should be contingent on the resolution of this problem within the country.

The Memorandum of Understanding was duly signed by the respective foreign ministers in Jakarta on August 8, 1990, and witnessed by President Suharto and Prime Minister Li Peng of the PRC. Interestingly, of the four paragraphs of the document, two deal with dual nationality (referring to Indonesian citizens of Chinese origin) and noninterference with each other's domestic affairs. ${ }^{7}$ This mention is widely seen as a recognition of the existence of the Chinese problem in Indonesia as indicated by the writings on ethnic Chinese that proliferated in the mass media around the event.

In view of this development, one might ask whether the government considers this problem resolved, in other words, that assimilation has been achieved, or that other considerations have prevailed and under the circumstances it is simply considered irrelevant. The

\footnotetext{
${ }^{5}$ Coordinating Body for the Chinese Problem, Pedoman, vol. 1.

6This appeal was made on March 4, 1990, when President Suharto invited thirty-one big businessmen (now popularly referred to as "conglomerates"), twenty-nine of them ethnic Chinese, to his cattle ranch, Tapos, in the Bogor area. In a speech that lasted about 1.5 hours and was broadcast in its entirety on national TV the same evening, he exhorted them, now that they had become wealthy, not the least because of the opportunities given by the New Order government, to express their gratitude for this good fortune. The gist of his appeal was that big businesses should sell up to 25 percent of their shares to cooperatives. In this way, he contended. "social envy" (kecemburuan sosial), which can lead to social unrest, could be avoided. Small businesses, represented by cooperatives, would feel that they had a share in big business and that, therefore, they also had a stake in keeping them going. See Tempo, especially March 10 and April 14, 1990, for the names of the businessmen invited; see also Editor, April 14, 1990.

${ }^{7}$ From the English translation of the document.
} 
latter seems to be the case if one looks at trade relations, which have flourished since the signing of the Memorandum of Understanding on trade between the Chamber of Commerce and Industry of Indonesia and the PRC in 1985.8

A review of the regulations enacted by the New Order government to resolve the Chinese problem, how they have been implemented, and how the ethnic Chinese have responded to them follows.

\section{Regulations Concerning the Ethnic Chinese}

As indicated, the most comprehensive regulation was contained in the instruction of June 1967 on the basic policies for the resolution of the Chinese problem. This regulation spells out the rationale for allowing foreign nationals to continue to operate in Indonesia. The considerations put forward are as follows:

that in the framework of development, all resources should be marshalled, including those belonging to foreign nationals; that to accelerate the process of development the efforts of citizens should be increased, while the capital/financial resources and enterprises of foreign nationals should be put to use correctly in the right proportion; that in the spirit of the Pancasila philosophy, the principles of a state based on law, and motivated by the desire to have good relations with all countries ... it is necessary to reevaluate, review, the policies concerning foreign nationals, in particular the Chinese problem. ${ }^{9}$

These instructions were to be implemented by "all bodies and the apparatus of the government, both civil and military, by the central as well as the local governments." ${ }^{10}$ It was also stipulated that they were specifically directed toward Chinese foreign nationals. They deal with the requirements for obtaining a work permit and a license to operate an enterprise and with foreign capital that is considered "foreign domestic capital" and is, therefore, "national wealth that is in the hands of foreign inhabitants, and as such should be marshalled, developed and made use of, for the benefit of rehabilitation and development." The government does not permit this foreign domestic capital to be transferred abroad.

The regulation includes a section that urges children of foreign nationals who have become residents of Indonesia to attend government as well as private schools that follow the national curriculum. An item on organization stipulates that with the permission and control of local authorities, only organizations related to health, religion, death, sports, and recreation will be allowed in certain areas with a sufficient number of foreign nationals. In addition, there is a special section on relations with the PRC; relations at that time were extremely strained but not yet severed (they dissolved four months later in October 1967).

The final part of this instruction concerned the implementation of the regulation and the August 1967 establishment of a special staff, Staf Khusus Urusan Cina, or SKUT (Special Staff for Chinese Affairs), which was directly responsible to the chairman of the Cabinet Presidium, that is, the president. Charged with the task of assisting the minister of political affairs in the resolution of the Chinese Problem, the special staff was responsible for coordinating and monitoring the implementation of the policies, especially those related to the

\footnotetext{
${ }^{8}$ Signed by the Indonesian Chamber of Commerce and Industry and the China Council for the Promotion of International Trade on July 5, 1988, in Singapore. After the historic meeting in Tokyo in April 1988 between President Suharto and the foreign minister of the PRC, when the foundation was laid for the resumption of diplomatic relations, technical follow-up meetings occurred.

${ }^{9}$ See n. 3, this article.

10 Ibid.
} 
Chinese Problem. In the discharge of its task, the special staff could cooperate with other government agencies or with relevant private organizations. ${ }^{11}$

Two regulations, which could be considered elaborations on the instruction, were probably generated by this special staff: the instruction on religion, beliefs, and Chinese customs implemented in December 1967 and the basic policies concerning Indonesian citizens of foreign descent. ${ }^{12}$ The first document was directed to the ministers of Religious Affairs and Internal Affairs and to other relevant government agencies on the central and local levels and concerned those aspects of Chinese religious behavior that showed cultural affinity with their country of origin. According to this instruction, such religious beliefs should only be expressed privately, and festivals related to Chinese religion and Chinese tradition should be celebrated within the confines of the home.

The second document deals specifically with Indonesian citizens of Chinese descent. It reiterates that before the law all citizens, including those of foreign descent, have the same rights and responsibilities. It also stipulates that they should be guided through the process of assimilation in order to avoid so-called racial exclusiveness. Furthermore, it states that discrimination does not exist because citizens of foreign descent are given the same opportunity as indigenous citizens "to marshall resources in all fields in order to accelerate development." Those with Chinese names, however, are urged to change them to Indonesiansounding names.

Another regulation included in the Resolution of the Provisional People's Consultative Assembly no. 32, 1966 concerns the use of Chinese language and script in the mass media. It states that there will be only one Chinese-language newspaper (subsequently called Harian Indonesia), sponsored and controlled by the government.

As mentioned earlier, a number of regulations concerned education. Because Chineselanguage schools had been central to the perpetuation of Chinese culture, these regulations deserve careful attention. Chinese schools have had a history of trials and tribulations that dates to the late 1950s, when the Central Military Command ordered all schools set up by organizations of "orang-orang Tionghoa Perantauan (Hoa Kiaw)" who were not citizens of a country that had diplomatic relations with Indonesia (in this case, Taiwan) to be closed. They were closed in October 1958. In 1957, schools with the same type of sponsorship in the Nusa Tenggara area were prohibited by order of the regional military command. ${ }^{13}$ These actions put an end to all schools set up by the Kuomintang or its sympathizers. In line with Indonesia's one-China policy, however, schools sponsored by PRC organizations were still allowed to operate. In the aftermath of the 1965 upheaval, violence was directed toward them, and they were also ordered to close. This prohibition was formalized by the decision of the minister of Education and Culture in July 1966.

\footnotetext{
11 Laporan Tahunan 1968, Staf Urusan Cina (Jakarta: Kabinet Pembangunan Republik Indonesia, 1968).

${ }^{12}$ See Presidential Instruction no. 14/1967 signed by Suharto, then acting president on December 6, 1967, and Presidential Decision no. 240/1967 on basic policies concerning Indonesian citizens of foreign descent.

${ }^{13}$ Sardjono Sigit, Asimilasi Pendidikan: Pokok-pokok Riwayat dan Permasalahannya (Jakarta: Departemen Pendidikan dan Kebudayaan, 1981) relates the history of foreign schools or international schools in Indonesia-the actions taken against the Dutch language schools in 1957, the Kuomintang Chinese language schools in 19571958, and the schools sponsored by the PRC and PRC sympathizers in 1965-1966; the banning of all Chinese language schools from 1966-1968 and the Special Project National Schools from 1968-1974; and the history of the laws for implementing assimilation in education and the regulations concerning foreign language and international schools.
} 
Nonetheless, in 1968, the government allowed a group of wealthy Chinese (known Taiwan sympathizers) to establish schools for the students of the banned schools because many of them could not be accommodated by existing schools. The Sekolah Nasional Proyek Khusus (Special Project National Schools) had to follow the national curriculum but were allowed to teach the Chinese language as an extracurricular activity. They became very popular; in 1970 there were eight schools in Jakarta, and by 1973 there were thirty-five schools in Sumatra alone. ${ }^{14}$

This development alarmed the government because some of the schools allegedly used Chinese as the medium of instruction. In 1974, the government closed them; the reason given was that the transitional period for the adjustment of former Chinese school pupils had terminated. This regulation marked the end of formal education in the Chinese language, thereby closing any avenue for systematic Chinese enculturation. Nonetheless, the government still thought that special instruction toward assimilation was necessary. The minister of Education then set up an assistance team for the implementation of assimilation in education and the regulation of foreign schools. These schools became known as Sekolah Pembauran. ${ }^{15}$

The implementation of the regulations concerned with the social and cultural lives of the ethnic Chinese was not as definitive and consistent as it was for regulations on education. In many situations, implementation was determined by the attitude of the local authorities toward ethnic Chinese. For example, activities in Chinese temples continued, and in some of the renowned ones-among others, the temple at Tanjungkait on the northern coast of Banten in West Java and the Sam Po Kong Temple in Semarang in Central Java-festivals are still drawing visitors from surrounding cities. These festivities have also started to spill outside the temple grounds, which could not have happened without permits from the local authorities.

On the other hand, in the beginning of 1989, a performance in Medan of the Chinese play Sam Pek Eng Thai (the Chinese version of Romeo and Juliette) adapted (the location was old-time Batavia) by the playwright Riantiarno of Teater Koma was abruptly canceled. Only on opening day did the authorities inform him that permission for the performance was not granted. The reason given was that because the opening day happened to be a national holiday, it would be inappropriate to have a public performance of a Chinese play. The authorities appeared to object also to the dragon dance in the play. It is interesting to note that the same play had been performed to wide acclaim in Jakarta in the prestigious Gedung Kesenian. Some months before that event, a similar fate befell an opera troupe from Taiwan. They were informed about the refusal of their permit after they had arrived in Jakarta.

The denial of permits in these two cases, in which the objection was against the Chineseness of the play or show, gives an impression of arbitrariness on the part of the authorities. Yet Mandarin movies and video cassettes from Hongkong may be shown or rented, and Mandarin-speaking entertainers regularly perform in hotels and nightclubs.

\footnotetext{
${ }^{14}$ Ibid.

${ }^{15}$ For a number of years when these schools began, I lectured to their supervisors (pengawas) on the cultural background of the ethnic Chinese to improve the supervisors' understanding of Chinese culture. During the discussion period, invariably at least one participant would comment on the problem faced of teaching the students Pancasila at school, only to have them influenced by Chinese culture at home. The question then raised was What can be done to eliminate this influence of Chinese culture?
} 
A review of the implementation of the regulations indicates that the government has enforced most consistently restrictions on Chinese-language schools, the use of Chinese script in public places, and the sale of Chinese-language publications.

\section{Responses of the Ethnic Chinese}

Scholars studying the ethnic Chinese ${ }^{16}$ still tend to treat them as a monolithic entity by referring to all of them as "Chinese" or "overseas Chinese." In Indonesia, this tendency is apparent among the majority population in the use of the terms orang Cina, orang Tionghoa ${ }_{L}$ or even hoakiau. ${ }^{17}$ I contend that these terms only apply to those who are alien, not of mixed ancestry, and who initially do not plan to stay in Indonesia permanently. The terms and the definition used for this group have important implications culturally, socially, and psychologically, especially for policy considerations and policy implementation.

As indicated in recent writings, the term commonly used today to refer to the group as a whole is "ethnic Chinese," regardless of citizenship, cultural orientation, or social identification. "Ethnic Chinese" refers to a group with cultural elements recognizable as or attributable to Chinese culture, whereas socially, members of this group identify with and are identified by others as a distinct group.

To identify the ethnic Chinese in Indonesia, however, is not easy. First they must be differentiated by citizenship into aliens and citizens and then by cultural orientation and social identification. Cultural orientation and social identification are a continuum. At one end are those, mostly of the younger generation, who identify completely and solely as Indonesian and whose cultural orientation is also Indonesian. Examples of individuals in this category are the late Soe Hok Gie, a student activist during the 1965-1966 upheaval, and his social scientist brother, Arief Budiman, who is known for his critical views of the development process in Indonesia, and who is married to a Minangkabau woman. Then there are Jusuf Wanandi, one of the directors of the Center for Strategic and International Studies, his brother, Sofjan Wanandi, one of the big businessmen, and Christianto Wibisono, director and owner of the nationally known Indonesian Business Data Center. All of them were prominent student activists during the 1965-1966 upheaval and are known as members of the "1966 generation."

There are also artists, like the nationally renowned playwright and film director Teguh Karya; Teguh Srimulat, the owner-director of the long highly popular folk theater, Srimulat; and the famous comedian, Ateng. One should also mention sports figures like Verawati Fadjrin, who several times became women's champion in international badminton competitions; she is a convert to Islam and is married to an ethnic Indonesian businessman. ${ }^{18}$

A number of exceptional figures belong at this end of the continuum. K. Sindhunata, a Catholic peranakan, is a lawyer and officer in the Indonesian Navy (now retired), who in the

\footnotetext{
${ }^{16}$ This section on the responses of the ethnic Chinese to the aforementioned government regulations is based mainly on Mély G. Tan, "The Role of the [sic] Ethnic Chinese Minority in Development: The Indonesian Case," Southeast Asian Studies, 25, (3) (December 1987): 63-83.

${ }^{17}$ The terms orang Cina and orang Tionghoa are Indonesian for "Chinese," whereas hoakiau is a Chinese (Hokkien) term meaning "overseas Chinese." It should be noted that the term Cina, or Cino in Javanese, is still considered by ethnic Chinese to have a derogatory meaning, especially in Java.

${ }^{18}$ These names can be found in Apa dan Siapa Sejumlah Orang Indonesia 1983-84 (Who's Who in Indonesia 198384), comp. Tempo (Jakarta: Grafitipers, 1984). A biography recently appeared of Teguh Srimulat, who is not generally known to be of Chinese origin, which mentions the Chinese names of his parents. See Herry Gendut Janarto, Teguh Srimulat. Berpacu dalam Komedi dan Melodi (Jakarta: Gramedia, 1990), p. 24.
} 
early sixties was one of the initiators of a group that became known as assimilationists. Haji Junus Jahja, a Dutch-educated economist, became known because of his well-publicized view that the solution to the Chinese problem is the mass conversion of the ethnic Chinese to Islam. Yet another exceptional figure is the businessman Bob Hasan, known as the "Rattan King," who also is the main promoter and financier of popular sports events.

At the other end of the continuum are those people usually referred to as totok, who are Chinese oriented culturally. They typically have had a Chinese-language education and speak Mandarin or one of the Chinese dialects with one another. Most have Indonesian citizenship through naturalization or, if born in Indonesia, through the various laws enacted and implemented in the 1950s and 1960s. Some of the businessmen often referred to in the foreign press fall in this category: Liem Sioe Liong, or Sudono Salim; Mochtar Riady; The Nin King; Go Swie Kie; and Eka Tjipta Wijaya, among others. ${ }^{19}$

Between these two categories is a whole range of people in various stages of acculturation to and identification with Indonesian society, who are commonly referred to as perana$k a n$, people of mixed ancestry. Their daily language is Indonesian, spoken often along with the local language of the region in which they were born. Many have become Protestant or Catholic; more recently, some have converted to Islam.

How have the ethnic Chinese responded to these measures that directly or indirectly affect their cultural and social lives? A brief review of their thinking and actions shows that they have been by no means united in their efforts to find a solution to the Chinese problem. Four lines of thought have emerged since independence. ${ }^{20}$

The most notable line of thought was propounded by Baperki, the ethnic Chinese mass organization mentioned earlier, which was formed in March 1954. From the beginning, this organization received the support of the ethnic Chinese, but when it became closely associated with the Indonesian Communist party under the leadership of the late Siauw Giok Tjhan, many of the other leading figures resigned. The line of thought proposed by this organization was integration, by which they meant the acceptance of the ethnic Chinese as a $s u k u$, or ethnic group, similar to indigenous ethnic groups. Thus, the group would be considered an integral part of Indonesian society without being dissolved as a sociocultural entity. In Siauw's view, this situation would be achieved only when Indonesia became a Socialist state. After the 1965 coup, Baperki was banned, and its leaders were detained.

The opposite view was expounded by a group mostly of young intellectuals, who in March 1960 announced a "statement of assimilation" in the magazine Star Weekly. This proclamation was the start of a movement that espoused the complete dissolution of the group and its absorption into various indigenous ethnic groups. Members of this group

\footnotetext{
${ }^{19}$ For an expose of the business activities of these figures see, among others, Richard Robison, Indonesia: The Rise of Capital (North Sydney: Allen and Unwin, 1986); Yoshihara Kunio, The Rise of Ersatz Capitalism in Southeast Asia (Singapore: Oxford University Press, 1988); and Yoon Hwan Shin, "Demystifying the Capitalist State: Political Patronage, Bureaucratic Interests, and Capitalist-in-Formation in Soeharto's Indonesia" (Ph.D. diss., Yale University, 1989).

${ }^{20}$ The ideas propounded by Baperki, Yap Thiam Hien, and the assimilationists are based on various writings in Leo Suryadinata, Political Thinking of the Indonesian Chinese 1900-1977, A Source Book (Singapore: Singapore University Press, 1979). For the assimilationists, see also Charles Coppel, Indonesian Chinese in Crisis (Kuala Lumpur: Oxford University Press, 1983). The ideas of Junus Jahja are taken from Junus Jahja, Zamam harapan bagi keturunan Tionghoa: Rekaman dakwah Islamiyah 1979-1984 (Era of hope for the people of Chinese descent: A recording of the propagation of Islam 1979-1984), ed. Junus Jahja (Jakarta: Yayasan Ukhuwah Islamiyah, 1984). See also, idem, Catatan Seorang WNI. Otobiografi (Notes of an Indonesian citizen. Autobiography) (Jakarta: Yayasan Tunas Bangsa, 1988).
} 
became part of the Lembaga Pembinaan Kesatuan Bangsa (Institute for the Promotion of National Unity), or LPKB. This group was not a mass organization but consisted of a full board of officers with specified tasks. Known as the assimilationists, they received the support of the government and especially of the military. From its inception to the present, the leading figure in this group has been K. Sindhunata, mentioned earlier. After 1965, the group continued to receive support from the government, and in 1977, changed its name to Bakom-PKB (Badan Komunikasi Penghayatan Kesatuan Bangsa or Communication Body for the Appreciation of National Unity). This organization came under the aegis of the Department of Internal Affairs.

Yet another view was proposed by the late Yap Thiam Hien, a prominent lawyer and Christian church leader. His ideas have been called pluralist by Suryadinata. I prefer the term religionist, however, for they are based on his deep sense of religion and his total commitment to fundamental human rights. The "therapies" he proposed were "heartcleansing," a change in attitude to becoming "Christian-centered" and "the rebirth of man in Jesus Christ," hence the term religionist. His was a rather lone voice because most ethnic Chinese consider it improbable that a Christian approach would receive a favorable response in a predominantly Muslim society.

More recently, another religionist approach emerged with the ideas of Junus Jahja, an activist of the LPKB who continued as an officer of the Bakom-PKB. He became a Muslim in June 1979, married a Muslim woman a few years later, and served as a member of the prestigious Majelis Ulama Indonesia Pusat (Central Council of Indonesian Ulamas) for the period 1980-1985.21 Junus espouses the idea that the solution to the Chinese problem lies in the mass conversion of the group to Islam. In his opinion, sharing the same religion would remove all the barriers between the majority ethnic Indonesians and the minority ethnic Chinese. To this end, he set up a foundation called Yayasan Ukhuwah Islamiyah (Foundation for Islamic Brotherhood) as the vehicle to spread Islam among the ethnic Chinese. He is quite realistic about its limited prospects for success, however, and acknowledges that despite favorable press coverage from 1979 througth 1984 only an estimated twenty thousand converted; at one point he had mentioned a target of about two hundred thousand.

Of these four lines of thought, only the Bakom-PKB and Junus Jahja's Muslim group are still active and vocal today. The Bakom-PKB has an executive board in most cities that have sizable ethnic Chinese communities. The appointment of prominent ethnic Chinese to the board is with the blessing of the local office of the Bureau for Social and Political Affairs of the Department of Internal Affairs. In many ways, this board functions as a liaison between the government and the ethnic Chinese community. Junus Jahja with his Ukhuwah Islamiyah foundation seeks to recruit new converts and deepen the knowledge of Islam of those already converted by encouraging them to open their homes for prayer meetings and religious study. Junus's efforts have the full support of the Muslim leadership and prominent people in the government.

To what extent do ethnic Chinese share the idea of assimilation either through absorption in the various ethnic groups of their regions as propounded by the assimilationists or through conversion to Islam as advocated by Junus Jahya? Neither of these approaches appears to be attractive to most ethnic Chinese; they see the first as having coercive

\footnotetext{
${ }^{21}$ Another ethnic Chinese who served in the council was the late Abdul Karim Oey, a Moslem of long standing. No doubt the late Hamka, prominent Moslem leader and thinker, played an important role in these conversions and in bringing these new converts into the mainstream Moslem group.
} 
elements and the second, conversion to Islam, as too drastic, a measure that would require a complete change in one's way of life.

The approach most favored is usually stated as "secara wajar" (in a natural way), through a process of sharing important aspects of life in education, work, and organizational spheres with indigenous Indonesians. This approach is carried out primarily on the individual level. This natural process is facilitated, for example, by participation in the activities of mainstream social organizations and political parties. This phenomenon is by no means new; after independence, individual ethnic Chinese became active members of existing political parties. Following the 1965 abortive coup, however, ethnic Chinese as a group tended to refrain from active participation in politics, although a few individuals continued to do so in a low-key way.

Recently, however, this low-profile attitude has given way to a more visible stance. For example, during the campaign period in the parliamentary election of April 1987, Dutcheducated economist and businessman Kwik Kian Gie came to the fore in the smallest camp of the three contestants in the election, the Partai Demokrasi Indonesia (PDI), or Indonesian Democratic Party. His activities rated mention in the Far Eastern Economic Review: "The diverse nature of the party's appeal has been symbolized by the appearance of ChineseIndonesian PDI leader Kwik Kian Gie at major rallies." The article also noted that "Kwik, a leading businessman, has even highlighted his Chinese origin in at least one PDI rally."22 It remains to be seen whether this is an isolated phenomenon or the beginning of a trend toward greater participation and fuller acceptance for ethnic Chinese in the sociopolitical arena.

Other changes are taking place in the social and cultural lives of the ethnic Chinese, especially among the younger generation. For instance, changing patterns of education have led to generational differences in language use at home and among members of the ethnic Chinese community, especially in Java. Whereas among the older generation some still speak good Mandarin or a mixture of Mandarin, Malay-Indonesian, and Javanese; and a very few speak fluent Dutch or a mixture of Malay-Indonesian with Dutch loanwords, the younger generation speaks only Indonesian or a mixture of Malay-Indonesian. ${ }^{23}$

There have also been changes in religion. The younger generation is moving away from traditional "Chinese religion," which in Indonesia consists primarily of ancestor veneration at home and of certain Chinese festivals, toward conversion to Catholicism or Protestantism and, more recently, to Islam. It is not uncommon in ethnic Chinese families today to find the children Catholic or Protestant, the mother still adhering to Chinese religion, and the father not professing any religion at all. Yet, on his identity card he may claim to be Buddhist or even Protestant, for since the 1965 upheaval, to leave the category for religion blank exposes him to suspicion that he is a Communist.

Interethnic marriage is also occurring but mostly when both parties are Christian. The incidence of marriage when one of the parties is Muslim is much lower. For instance, a study in Jakarta shows that of the 175 ethnic Chinese-ethnic Indonesian marriages recorded

\footnotetext{
${ }^{22}$ Far Eastern Economic Review, April 23, 1987. Recently, Kwik sold his business, an agency for European electronic equipment, apparently "in order to devote himself entirely to politics." He was rumored to be on the verge of bankruptcy, probably because his outspoken criticism of certain business policies and practices made it difficult for him to keep his business going.

${ }^{23}$ This language use by ethnic Chinese in Pasuruan, a small town in East Java, is described in Oetomo, "Chinese of Pasuruan," pp. 455-63, 467-527. This is a clear example of the cultural variety within the ethnic Chinese group, which is also based on age and "social class."
} 
at the Civil Registration Office in 1982 only 13 percent were between Christians and Moslems. ${ }^{24}$ Apparently, the parents of both parties play an important role in these cases. On the Muslim side is the requirement that the non-Muslim party convert to Islam, whereas on the non-Muslim side, especially if the child is a daughter, the gravest parental concern is that, because in Muslim law a man is allowed to have more than one wife, she may find herself in the position of having to share her husband, or if she refuses to be made a co-wife, requesting a divorce.

An aspect that has not changed much is the persistence of stereotypes. Among ethnic Chinese the view persists that ethnic Indonesians are unwilling to work hard, that they are wasteful, and that "if they have no money, they will ask from us, sometimes with a veiled threat"; hence "as long as they like money, we are safe." 25 Conversely, the stereotypes among ethnic Indonesians about ethnic Chinese also persist that they are very rich; that they are only out to make as much money as possible; that they are arrogant and feel superior, which is reflected in their tendency to be "exclusive," that is, to segregate in plush real estate areas and to stay away from neighborhood mutual help activities.

Mutually negative stereotypes also persist among totok and peranakan that reflect the continuing lack of social interaction between them. In a study in Solo, researchers found that more totok than peranakan have become Muslim. Peranakans who were asked about this finding opined that the totok convert to Islam because they think it is advantageous for business, intimating that the totok will do anything to promote their businesses. The totok, on the other hand, look down on peranakan as "wong londo" (Dutch) because they speak Dutch among themselves, or as pribumi because they speak Malay-Indonesian or Javanese only. The totok especially resent Dutch-speaking peranakan because they see such language use as an expression of peranakan feelings of superiority. ${ }^{26}$

The attitude of the younger generation of ethnic Chinese toward their position in Indonesian society deserves closer examination. This group experienced neither the colonial regime, when the population was systematically divided by race, the Japanese occupation, when all ethnic Chinese were treated as one group, the turbulence of the revolution, when ethnic Chinese were accused of collaborating with the Dutch, nor the controversy about assimilation and integration in the latter part of the Sukarno era. They do know that during the upheaval of 1965-1966, ethnic Chinese youths participated in the demonstrations against the Sukarno government and that some of them were recognized as leading figures in the then strong and influential student movement.

As a result, they seem more positive about their identity as Indonesians. At the same time, this identification makes them feel more frustrated when they experience discrimination. For instance, a special code is attached to the serial number of their identity cards and passports, indicating that they are citizens of foreign descent. ${ }^{27}$ They resent the fact that

\footnotetext{
${ }^{24}$ Sutedjo, "Komunikasi," pp. 66-68.

${ }^{25}$ Oetomo, "Chinese of Pasuruan," pp. 134-41.

${ }^{26}$ Indrakusuma, "Posisi berbeda agama," pp. 63-76. See also, Oetomo, "Chinese of Pasuruan," p. 436.

${ }^{27}$ This matter came up at a seminar organized by Tarumanegara University (a private university with a predominantly ethnic Chinese student body) on March 10,1990, on the occasion of the establishment of a center for the study of nation building (Pusat Kajian Kesatuan dan Persatuan Bangsa). The keynote speech was given by Minister of Internal Affairs Rudini. During the discussion period, one of the faculty members, a pribumi who teaches kewiraan, which includes civics, asked about the special codes. As he put it, when his students asked him about this, he was at a loss about how to answer them. The minister replied that he would look into it, and if this really were true, it should immediately be stopped. Apparently, in Jakarta, those of foreign descent (Chinese, Arab, Indian, Dutch) have a zero in the group of numbers after the serial number of the village (kelurahan). According to
} 
assimilation is a one-way process; only they are expected to adjust and comply. Hence according to the results of a recent study in Sukabumi, ${ }^{28}$ the younger generation tends to withdraw within its own group and to strengthen its ethnic Chinese identity. If they don't emphasize their Chineseness, they at least see themselves as different from the ethnic Indonesians.

The feeling of being discriminated against, even after having complied with all the New Order regulations pertaining to their social and cultural lives, has given rise to an assertiveness that is new to the ethnic Chinese. This attitude is expressed in an insistence on the consistent implementation of the principle of two types of citizenship only: the Warga Negara Republik Indonesia or WNRI or WNI (Indonesian citizen) and the Warga Negara Asing or WNA (alien), meaning that all citizens should be treated the same, regardless of ethnic origin, and similarly, all aliens should be treated the same, including those of Chinese origin. This view has been stated on many occasions by Sindhunata as chairman of the Bakom-PKB and by Lie Tek Tjeng, a historian affiliated with the Indonesian Institute of Sciences (LIPI) and a widely recognized (including by the military) expert on IndonesiaChina relations.

Furthermore, expression of the view that assimilation should not necessarily mean the disappearance of the ethnic Chinese as a group is increasingly open. For instance, Harry Tjan Silalahi, one of the directors of the Center for Strategic and International Studies and a former member of the People's Consultative Assembly (MPR), was quoted in an interview in Suara Pembaruan, the major afternoon paper, as saying, "Assimilation should not eliminate diversity" (pembauran jangan menghilangkan kebhinekaan). He stated that assimilation cannot be forced on people but should be promoted through persuasion and regulation. He went on to say that this should be done by creating situations in which the two groups can interact more freely. He suggested that this approach means providing more opportunities for ethnic Chinese to enter government schools, the army, and the civil service.

Sofjan Wanandi, who subsequently became the spokesman for the group of businessmen invited to Tapos, was quoted in a meeting of the Indonesian Chamber of Commerce and Industry as raising the question of why more pribumi big businessmen were not included in the meeting at Tapos, suggesting perhaps that this could be seen as exclusivism in reverse.

This kind of open questioning of the policy of assimilation and its implementation indicates a feeling among the ethnic Chinese of greater security in their identification as Indonesians, accompanied by a sense of being treated unfairly. Despite full compliance with the regulations governing their social and cultural lives, they feel they are still not appreciated, recognized, or accepted as full-fledged fellow citizens by the ethnic Indonesian majority. They now insist more strongly that assimilation should be a two-way street.

\section{Conclusion}

Clearly, basic changes are occurring among the ethnic Chinese in Indonesia. Changes are especially noted among the younger generation, many of whom have become Protestant, Catholic, and more recently, Muslim. These changes may reduce their visibility as ethnic Chinese, remove some of the sources of resentment, and thereby lead to reduced hostility

K. Sindhunata, chairperson of Bakom-PKB, the passports of those of foreign descent also have a special code (Tempo, March 17, 1990, also April 14 and April 28, 1990, in "Letters to the Editor").

${ }^{28}$ Suleeman, "Persepsi golongan keturunan," pp. 201-6. 
toward this group. No doubt the assimilationist policy of the government has been responsible for many of the changes.

It is clear that acculturation is an irreversible process and is continuing at a rapid pace. One must distinguish, however, between the process of acculturation and the process of social integration as indicated by social interaction. The former is proceeding linearly as Chinese cultural elements disappear and elements of local culture are adopted. One can even talk about the emergence of an "urban culture," in particular, "Jakarta culture," to which the ethnic Chinese have contributed. However, the process of social integration as manifested in social interaction is still not going smoothly. Contrary to their expectations, although members of the younger generation of ethnic Chinese state that they identify as Indonesians, they do not feel entirely appreciated and accepted by the ethnic Indonesian majority. Frustration has generated an assertiveness expressed in an insistence that the principle of two types of citizenship, Indonesian citizens (WNRI) and aliens (WNA), be implemented consistently and that efforts be mutual.

One should be mindful that the role of ethnic Chinese in the Indonesian economy is still perceived by the ethnic Indonesian majority as very powerful. With the recent policies of deregulation, especially in banking, generating a proliferation of new banks or new branches of existing banks and causing the rush of companies (many of which are owned by ethnic Chinese) to "go public," their role in the economy is viewed as even more pervasive than before. The stereotype that all ethnic Chinese are wealthy and that they have benefited most from "facilities" made available by the New Order government and become big businessmen in the process has undoubtedly been reinforced by the event at Tapos. Hence although basic changes are occurring in the social and cultural dimensions of their lives, their role in the economy is the most visible to ethnic Indonesians and is the major source of resentment against them. It is imperative, therefore, that changes also occur in the economic arena.

Does normalization of relations with the PRC have any relevance to the Chinese problem? It is implicitly recognized in the Memorandum of Understanding that marked the resumption of diplomatic relations between the two countries. Yet as indicated in the many writings on the ethnic Chinese in Indonesia that appeared in the media at the time, it is uncertain the Chinese problem has been resolved.

However, ultimately the government, its policies, and the implementation of these policies will determine whether relations between the ethnic Chinese minority and the ethnic Indonesian majority will continue to be characterized by periodic outbursts of social unrest with the ethnic Chinese remaining victims of scapegoating and deflected aggression or whether a gradual but continuous reduction in conflict situations will occur.

The ethnic Chinese should realize that it is imperative to diversify occupationally and residentially and to move away from overconcentration in economic activities and certain exclusive neighborhoods. They should realize that, having elected to become Indonesian citizens, they must pay equal attention to their responsibilities as well as their rights as citizens. Furthermore, as a minority group they are compelled to find ways to achieve an acceptable accommodation with the majority population. On the other hand, for individuals, total assimilation is a course of action still as open today as it was in the past. 
